\title{
TUGAS DAN KEWENANGAN PEJABAT PERBENDAHARAAN NEGARA DITINJAU DARI UNDANG-UNDANG NOMOR 30 TAHUN 2014 TENTANG ADMINISTRASI PEMERINTAHAN
}

\author{
Oleh : HERYANTO SIJABAT, S.H., M.H. ${ }^{*}$
}

\begin{abstract}
Treasury officials are government officials who perform duties and authority in the management of state finances. The official legal consequences should generally be subject to the regulations governing public administration. Based on the legal paradigm in public administration, Treasury officials in exercising its authority is limited to the period or the time limit of authority, regional or local authority and the enactment of the field or the material scope of authority. Prohibition of abuse of authority by officials repertory includes a ban on the activity exceeds authority, prohibition of mixing up authority and the prohibition on acting arbitrarily.

Keywords : Authority, Officials Pembendaharaan State.
\end{abstract}

\section{ABSTRAK}

Pejabat Perbendaharaan merupakan pejabat pemerintahan yang melakukan tugas dan kewenangan dalam pengelolaan keuangan negara. Akibat hukumnya pejabat tersebut harus tunduk secara umum kepada peraturan yang mengatur tentang administrasi pemerintahan. Berdasarkan paradigma dalam hukum administrasi pemerintahan, Pejabat Perbendaharaan dalam melaksanakan kewenangannya dibatasi dengan masa atau tenggang waktu wewenang, wilayah atau daerah berlakunya wewenang dan cakupan bidang atau materi wewenang. Larangan penyalahgunaan Wewenang oleh pejabat perbendaharaan meliputi adanya pelarangan aktifitas melampaui wewenang, pelarangan mencampuradukkan Wewenang dan pelarangan untuk bertindak sewenang-wenang.

Kata Kunci : Kewenangan, Pejabat, Pembendaharaan Negara.

\section{PENDAHULUAN}

Penerapan prinsip good
govenanceis a must dalam
pemerintahan yang transparan dan
bertanggungjawab merupakan salah
satu ciri dari dilaksanakannya
transformasi dan reformasi.

Transformasi dan reformasi dilakukan dengan mengatur kembali peraturan perundang-undangan sebagai landasan hukum keuangan negara, penataan kelembagaan keuangan negara, Penataan ulang sistem pengelolaan keuangan negara dan Pengembangan sumber daya manusia di bidang keuangan negara.

Transformasi dan reformasi pengelolaan keuangan negara mulai dilakukan dengan dikeluarkannya paket perundang-undangan yaitu UndangUndang Nomor 17 Tahun 2003 tentang keuangan negara, Undang-undang Nomor 1 tahun 2004 tentang perbendaharaan negara dan Undang-

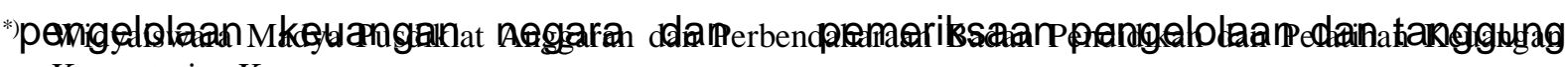
Pengembaniangan Kunmber daya manusia jawab keuangan negara.
}

di bidang keuangan negara. 
undang Nomor 15 tahun 2004 tentang pemeriksaan pengelolaan dan tanggung jawab keuangan negara.

Alasan-alasan

dilakukannya

transformasi dan reformasi pengelolaan keuangan negara antara lain fungsi perencanaan yang belum tegas benang merahnya dengan penganggaran, institusi penganggaran yang terbelah antara anggaran rutin dan pembangunan, anggaran yang berorientasi pada input bukan output atau outcomes, landasanpelaksanaanhakbujetlegislatif yang belumtersedia, fungsifinancial management yang tidakterpadu, danfungsioperasional yang belum optimal (let the managers manage), dukunganpembiayaanalternatif yang belum tersedia setelah independensi $\mathrm{BI}$, penyelenggaraan fungsi treasury (kas, piutang, utang, investasi, aset lain) yang jauhdari optimal, tanggungjawab kementerian / lembaga terhadap penggunaan anggaran belum cukup tegas, belum tersedia standar akuntansi bagi pelaporan keuangan pemerintah, laporan keuangan hanya meliputi realisasi anggaran dan penyajiannya sangat lambat dan yang terakhir fungsi pemeriksaan yang kurang efektif dan tumpang tindih.

Penegasan tugas dan kewenangan pejabat perbendaharaan yang merupakan pejabat yang melakukan pengelola keuangan negara pada kementerian/lembaga diperjelas agar tidak tumpang tindih. Hal ini diatur dalamperaturan Pemerintah Nomor 45 tahun 2013 tentang tata cara pelaksanaan Anggaran Pendapatan dan Belanja Negara. Pejabat perbendaharaan adalah Pengguna Anggaran (PA), Kuasa Pengguna Anggaran (KPA), Pejabat Pembuat Komitmen (PPK), Pejabat Penandatangan Surat Perintah Bayar (PPSPM), Bendahara Umum Negara (BUN), Bendahara Penerimaan, dan Bendahara Pengeluaran.

Dalam prakteknya para pejabat perbendaharaan memiliki "phobia" ketika melaksanakan tugas dan kewenangannya dikarenakan tidak ada jaminan hukum dalam pelaksanaan tugasnya. Seluruh keputusan yang diambil oleh pejabat perbendaharaan dapat diseret ke ranah pidana khususnya tindak pidana korupsi walaupun sebenarnya masih ranah administrasi pemerintahan.

\section{Tugas dan Kewenangan Pejabat Perbendaharaan Negara}

1. Pengguna Anggaran.

Pengguna

Anggaran (PA)merupakan seorang pejabat yang menjadi pemegang kewenangan 
penggunaan anggaran Kementerian Negara/Lembaga. Menteri dan Pimpinan Lembaga selaku penyelenggara urusan tertentu dalam pemerintahan merupakan PA atas bagian anggaran (BA) yang disediakan untuk penyelenggaraan urusan pemerintahan yang menjadi tugas dan kewenangannya. Khusus untuk Menteri Keuangan, selain sebagai PA atas bagian anggaran untuk Kementerian Keuangan, juga bertindak selaku PA atas bagian anggaran yang bukan merupakan bagian anggaran Kementerian Negara/Lembaga tertentu contohnya Bagian Anggaran Bendahara Umum Negara (999).

Selanjutnya Menteri dan Pimpinan Lembaga bertanggung jawab secara formal dan materiil kepada Presiden atas pelaksanaan kebijakan anggaran

Kementerian

Negara/Lembaga yang dikuasainya.Yang dimaksud dengan pertanggung jawaban formal dari PA adalah tanggung jawab atas pengelolaan keuangan Kementerian Negara/Lembaga yang dipimpinnya. Sedangkan Tanggung jawab materiil adalah tanggung jawab atas penggunaan anggaran dan hasil yang dicapai atas anggaran negara yang telah diterimanya. Pengguna Anggaran (PA) memiliki wewenang untuk menunjuk kepala Satuan Kerja yang melaksanakan kegiatan Kementerian Negara/Lembaga sebagai Kuasa Pengguna Anggaran (KPA) dan menetapkan Pejabat Perbendaharaan lainnya. Termasuk Pengguna Anggaran (PA) dapat melimpahkan kepada KPA penetapan pejabat perbendaharaan lainnya atau untuk hal tertentu, PA dapat menunjuk pejabat selain kepala Satuan Kerja sebagai KPA.

\section{Kuasa Pengguna Anggaran (KPA)}

KPA yang ditetapkan oleh PA diberikan tugas dan wewenang dalam rangka pelaksanaan anggaran berupa penyusunan DIPA, menetapkan pejabat perbendaharaan lainnya (PPK, PPSPM, Bendahara Penerimaan, Bendahara Pengeluaran dan Bendahara Pengeluaran Pembantu), menetapkan panitia/pejabat yang terlibat dalam pelaksanaan kegiatan dan anggaran, menetapkan rencana pelaksanaan kegiatan dan rencana pencairan dana, melakukan tindakan yang mengakibatkan pengeluaran anggaran Belanja Negara, melakukan pengujian tagihan dan perintah pembayaran atas beban anggaran negara, memberikan supervisi, konsultasi, dan pengendalian pelaksanaan kegiatan dan anggaran, mengawasi penatausahaan dokumen dan transaksi yang berkaitan dengan pelaksanaan kegiatan dan anggaran 
serta menyusun laporan keuangan dan kinerja sesuai dengan Peraturan Perundang-undangan.

Sama halnya dengan PA yang bertanggungjawab secara formal dan materil kepada Presiden, KPA juga memberikan pertanggungjawaban secara formal dan materiil kepada PA atas pelaksanaan Kegiatan yang berada dalam penguasaannya. Tanggung jawab formal tersebut merupakan tanggung jawab atas pelaksanaan tugas dan wewenang KPA sedangkan untuk pertanggungjawaban merupakan tanggung jawab atas penggunaan anggaran dan keluaran (output) yang dihasilkan atas beban anggaran negara.

\section{Pejabat Pembuat Komitmen (PPK)}

Defenisi Pejabat Pembuat Komitmen (PPK) agak berbeda dalam Peraturan Pemerintah Nomor 45 tahun 2013 dan Peraturan Presiden Nomor 54 tahun 2010 dan perubahannya. Pasal 1 angka 23 PP Nomor 45 tahun 2013 menerangkan yang dimaksud dengan Pejabat Pembuat Komitmen (PPK) adalah pejabat yang diberi kewenangan oleh PA/KPA untuk mengambil keputusan dan/atau melakukan tindakan yang dapat mengakibatkan pengeluaran anggaran belanja negara.Sedangkan dalam Pasal 1 angka 7 Peraturan Presiden Nomor 54 tahun 2010 pendefenisian Pejabat Pembuat
Komitmen merupakan pejabat yang bertanggung jawab atas pelaksanaan Pengadaan Barang/Jasa.

Apabila dilihat dari defenisi perundangan yang diatas maka pengertian PPK dalam PP nomor 45 tahun 2013 memiliki pengertian yang lebih luas dibandingkan Perpres Nomor 54 tahun 2010 yaitu PPK diberikan mengambil keputusan dan/atau melakukan tindakan yang dapat mengakibatkan pengeluaran anggaran belanja negara (belanja gaji, belanja barang, belanja modal, belanja sosial, hibah, bayar utang dan belanja lain-lain) bukan hanya bertanggungjawab atas pelaksanaan pengadaan barang jasa.

\section{Bendahara Umum Negara}

Undang-Undang Nomor 1 Tahun 2004 menetapkan Menteri Keuangan selaku Bendahara Umum Negara (BUN). Menteri Keuangan selaku BUN dapat mengangkat Kuasa BUN. BUN memiliki tugas dan wewenang yaitu :

a. membuka Rekening Kas Umum Negara untuk menampung seluruh penerimaan negara dan membayar seluruh pengeluaran negara pada bank sentral.

b. melaksanakan penerimaan dan pengeluaran Kas Negara dalam rangka pengendalian pelaksanaan anggaran negara. 
c. memerintahkan penagihan Piutang Negara kepada pihak ketiga sebagai penerimaan anggaran.

d. melakukan pembayaran tagihan pihak ketiga sebagai pengeluaran anggaran.

\section{Bendahara Penerimaan.}

Jika dibutuhkan dalam satuan kerja, Kuasa Pengguna Anggaran dapat mengangkat Bendahara Penerimaan. Bendahara Penerimaan memiliki tugas untuk menerima dan menyimpan uang Pendapatan Negara yang diterimanya. Selanjutnya uang tersebut disetorkan ke rekening Kas Negara secara periodik. Bendahara Penerimaan diwajibkan untuk menatausahakan dan membuat laporan pertanggungjawaban atas penerimaan uang yang diterimanya.

\section{Bendahara \\ Bendahara \\ Pengeluaran \\ Pembantu.}

Tugas Bendahara Pengeluaran melaksanakan fungsi kebendaharaan atas uang persediaan yang dikelolanya. Bendahara Pengeluaran dalam pekerjaan dapat dibantu oleh satu atau lebih Bendahara Pengeluaran Pembantu dengan tujuan untuk meningkatkan efektivitas dan efisiensi pelaksanaan anggaran belanja.

Bendahara Pengeluaran dapat melakukan pembayaran dari dana Uang
Persediaan. Pembayaran dilakukan atas permintaan dari Pejabat Pembuat Komitmen atas nama Kuasa Pengguna Anggaran. Bendahara Pengeluaran dapat menolak permintaan pembayaran apabila dokumen pendukung tidak lengkap, benar dan sah. Bendahara Pengeluaran juga memiliki kewajiban untuk memungut dan menyetorkan pajak atas setiap transaksi yang dilakukannya. Atas uang persediaan yang dikelolannya Bendahara Pengeluaran diharuskan membuat laporan pertanggungjawaban yang diserahkan kepada Kuasa BUN dan Badan Pemeriksa Keuangan (BPK).

Tugas dan Kewenangan Pejabat Perbendaharaan Negara Ditinjau Dari Undang-Undang Nomor 30 Tahun 2014 Tentang Administrasi

\section{Pemerintahan}

Undang-undang Nomor 30 tahun 2014 menegaskan administrasi Pemerintahan merupakan tata laksana dalam pengambilan keputusan dan atau tindakan oleh badan danatau pejabat pemerintahan. Para pejabat pemerintahan dalam pelaksanaan tugas dan kewenangannya bertindak dalam ranah hukum publik dan keputusan yang dikeluarkan merupakan ketetapan tertulis. Tugas dan kewenangan yang dilakukan dapat melakukan atau tidak 
melakukan sesuatu sesuai dengan jabatannya.

Sesuai dengan Undang-undang Nomor 30 tahun 2014, Pejabat Perbendaharaan merupakan pejabat pemerintahan yang melakukan tugas dan kewenangan dalam pengelolaan keuangan negara. Akibat hukumnya pejabat tersebut harus tunduk secara umum kepada peraturan yang mengatur tentang administrasi pemerintahan.

Dalam administrasi pemerintahan Pejabat Perbendaharaan memiliki hak dan kewajiban. Hak-hak antara lain :

1. Melaksanakan Kewenangan yang dimiliki berdasarkan ketentuan peraturan perundang-undangan dan Azas-azas Umum Pemerintahan Yang Baik.

2. Menyelenggarakan aktivitas pemerintahan berdasarkan Kewenangan yang dimiliki.

3. Menetapkan Keputusan dan atau tindakan berbentuk tertulis atau elektronis.

4. Menerbitkan atau tidak menerbitkan, mengubah, mengganti, mencabut, menunda, dan ataumembatalkan Keputusan'

5. Menggunakan Diskresi sesuai dengan tujuannya.

6. Mendelegasikan dan memberikan Mandat kepada Pejabat Pemerintahan lainnya sesuai dengan ketentuan peraturan perundangundangan.

7. Menunjuk pelaksana harian atau pelaksana tugas untuk melaksanakan tugas apabila pejabatdefinitif berhalangan,

8. Menerbitkan Izin, Dispensasi, dan atau Konsesi sesuai dengan ketentuan peraturan perundangundangan.

9. Memperoleh perlindungan hukum dan jaminan keamanan dalam menjalankan tugasnya.

10. Memperoleh bantuan hukum dalam pelaksanaan tugasnya.

11. Menyelesaikan

Sengketa Kewenangan di lingkungan atau wilayah kewenangannya.

12. Menyelesaikan Upaya Administratif yang diajukan masyarakat atas Keputusan

yang dibuatnya.

13. Menjatuhkan sanksi administratif kepada bawahan yang melakukan pelanggaran.

Sedangkan Kewajiban Pejabat Perbendaharaan Negara adalah :

a. Membuat Keputusan dan/atau Tindakan sesuai dengan kewenangannya.

b. Mematuhi Asas-asa Umum Pemerintahan yang Baik dan sesuai dengan ketentuan peraturan perundang-undangan. 
c. Mematuhi persyaratan dan prosedur pembuatan Keputusan dan/atau Tindakan.

d. Mematuhi Undang-Undang ini dalam menggunakan Diskresi.

e. Memberikan Bantuan Kedinasan kepada Badan dan/atau Pejabat Pemerintahan yang memintabantuan untuk melaksanakan penyelenggaraan pemerintahan tertentu.

f. Memberikan kesempatan kepada Warga Masyarakat untuk didengar pendapatnya sebelummembuat Keputusan sesuai dengan ketentuan peraturan perundang-undangan.

g. Memberitahukan kepada Warga Masyarakat yang berkaitan dengan Keputusan yang menimbulkan kerugian paling lama 10 (sepuluh) hari kerja terhitung sejak Keputusan ditetapkan dan atau dilakukan.

h. Menyusun standar operasional prosedur pembuatan Keputusan dan/atau Tindakan.

i. Memeriksa dan meneliti dokumen Administrasi Pemerintahan, serta membuka akses dokumenAdministrasi Pemerintahan kepada Warga Masyarakat, kecuali ditentukan lain oleh undangundang.

j. Menerbitkan Keputusan terhadap permohonan Warga Masyarakat, sesuai dengan hal-hal yang diputuskan dalam keberatan/ banding.

k. Melaksanakan Keputusan dan/atau Tindakan yang sah dan Keputusan yang telah dinyatakan tidak sah atau dibatalkan oleh Pengadilan, pejabat yang bersangkutan, atau Atasan Pejabat.

I. Mematuhi putusan Pengadilan yang telah berkekuatan hukum tetap.

Salah satu indikator bahwa Pejabat Perbendaharaan Negara telah melakukan administrasi pemerintahan adalah melaksanakan asas-asas umum pemerintahan yang baik. Asas-asas umum pemerintahan yang baik meliputi adanya kepastian hukum, kemanfaatan, ketidakberpihakan, kecermatan, tidak menyalahgunakan kewenangan, keterbukaan, kepentingan umum dan pelayanan yang baik. Termasuk juga berlaku asas-asas yang berlaku dalam pengelolaan keuangan negara. Contohnya : Pejabat Perbendaharaan dilarang mengeluarkan atau belanja apabila anggaran tidak tersedia dalam Daftar Isian Pelaksanaan Anggaran (DIPA). Azas umum yang lain seperti Pejabat Perbendaharaan diharuskan tidak boleh membayar barang jasa apabila barang jasa tersebut belum diterima kecuali untuk hal-hal yang diatur oleh peraturan seperti sewa kantor. Penggunaan sewa kantor baru 
dapat digunakan jika negara telah membayar terlebih dahulu biaya sewa kantor tersebut kepada penyedia.

Berdasarkan paradigma dalam hukum administrasi pemerintahan,Pejabat Perbendaharaan dalam melaksanakan kewenangannya dibatasi dengan masa atau tenggang waktu wewenang, wilayah atau daerah berlakunya wewenang dan cakupan bidang atau materi wewenang.Larangan penyalahgunaan Wewenang oleh pejabat perbendaharaan meliputi adanya pelarangan aktifitas melampaui wewenang, pelarangan mencampuradukkan Wewenang dan pelarangan untuk bertindak sewenangwenang.

Pejabat Perbendaharaan dapat melakukan diskresi dalam pengelolaan keuangan negara dengan alasan adanya ketentuan peraturan perundangundangan yang memberikan suatu pilihan. Termasuk juga jika perundangundangan tidak mengatur, tidak lengkap atau tidak jelas. Diskresi dapat juga dilakukan jikakarena adanya stagnasi pemerintahan guna kepentingan yang lebih luas.

Pelaksanaan $\begin{aligned} & \text { kewenangan } \\ & \text { diskresi }\end{aligned}$ Pejabat Perbendaharaan
diawasi oleh Aparat Pengawasan Intern
Pemerintah (APIP). APIP itu sendiri di
Kementerian/Lembaga biasanya adalah

tugas pokok dan fungsi dari Inspektorat Jenderal. Hasil pengawasan dari Inspektorat Jenderal dapat berupa rekomendasi tidak terdapat kesalahan, terdapat kesalahan administratif atau terdapat kesalahan administratif yang menimbulkan kerugian keuangan negara.

Yopie menjelaskan bahwa secara prinsip penyalahgunaan kewenangan dalam administrasi pemerintahan tidaklah sama dengan unsur melawan hukum khususnya dalam tindak pidana korupsi. Karenanya kedua unsur ini dipisahkan dalam Undang-Undang Tindak Pidana Korupsi. (Yopie Morya Immanuel Patiro : 176)

Jika dilihat dalam pasal 21 Undang-undang Nomor 30 tahun 2014, penetapan adanya penyalahgunaan kewenangan yang dilakukan pejabat perbendaharaan dalam pengelolaan keuangan negara dimintakan ke Pengadilan Tata Usaha Negara (PTUN). Putusan PTUN dapat diajukan banding kepada Pengadilan Tinggi Tata Usaha Negara dan menjadi putusan final.

Fathudin menyebutkan bahwa penyalahgunaan wewenang memang menuai kontroversi apakah menjadi domain hukum administrasi negara dengan Peradilan Tata Usaha Negara yang memiliki kompetensi absolutnya atau langsung ditarik ke ranah hukum 
pidana dalam hal ini Peradilan Umum. Pertanggungjawaban pidana pemegang jabatan dalam sistem hukum Indonesia, terutama kaitannya dengan tindak pidana korupsi, masih mendua di dalam mengedepankan asas pidana lex specialis systematic atau logische specialiteit terhadap administratif penal law dan masih menerapkan UndangUndang Pemberantasan Tindak Pidana Korupsi sebagai lex specialis. (Fathudin : 125).

\section{Kesimpulan :}

1. Segala Keputusan Pejabat Perbendaharaan dalam pengelolaan keuangan negara termasuk dalam ranah administrasi pemerintahan sesuai dengan Undang-Undang Nomor 30 Tahun 2014.

2. Pejabat Perbendaharaan dalam pengelolaan keuangan negara memiliki diskresi untuk kelancaran pembayaran sesuai dengan peraturan yang belaku.

\section{DAFTAR PUSTAKA}

Fathudin, Tindak Pidana Korupsi
(Dugaan
Wewenang) Penyalahgunaan
(Perspektif Pejabat Publik
Nomor 30 Tahun 2014 Tentang
Administrasi Pemerintahan),
Jurnal Cita Hukum. Vol. II No. 1
Juni 2015.

Yopie Morya Immanuel Patiro, Diskresi Pejabat Publik dan Tindak Pidana Korupsi, CV. Keni Media, Bandung, 2012. 
